Principles of good corporate governance

\title{
SELF ASSESSMENT PENERAPAN TATA KELOLA PT BANK MANDIRI (PERSERO) Tbk
}

\author{
Faradina Inda Wardhani \\ Inda.wardhani@gmail.com \\ Sekolah Tinggi Ilmu Ekonomi Indonesia Pontianak
}

\begin{abstract}
Good corporate governance $(G C G)$ is used by companies to improve the quality of earnings by taking into account the interests of stakeholders are based on the rule of law and norms. System of good corporate governance requires built and executable principles of corporate governance (GCG) in the process of managerial companies. The method used in this research is descriptive and verification method. Based on the research results, it can be concluded that the principles of good corporate governance at Bank Mandiri are measured using the dimensions of transparency, accountability, responsibility, independence and fairness in excellent criteria.
\end{abstract}

Keywords: Principles of good corporate governance,

\section{PENDAHULUAN}

Self assessment penerapan Good Corporate Governance (GCG) ditetapkan oleh peraturan otoritas jasa keuangan No. 55/PJOK.03/2016 dan Surat Edaran Bank Indonesia No 12/15/DPNP tanggal 29 April 2013. Penilaian sendiri good corporate governance (GCG) merupakan proses penilaian yang dilakukan oleh pihak internal untuk menetapkan kesimpulan pelaksaan tata kelola perusahaan. Peraturan Otoritas Jasa Keuangan (POJK) No.55/POJK.03/2016 dan Surat Edaran Bank Indonesia Nomor 15/15/DPNP tanggal 29 April 2013 perihal Pelaksanaan Good Corporate Governance bagi Bank Umum tentang Penerapan Tata Kelola Bank Umum, yang mewajibkan Bank untuk melakukan penilaian sendiri (self assessment) atas penerapan Tata Kelola Bank yang mencakup antara lain :

1. Pelaksanaan tugas dan tanggung jawab Dewan Komisaris

2. Pelaksanaan tugas dan tanggung jawab Direksi

3. Kelengkapan dan pelaksanaan tugas Komite

4. Penanganan Benturan Kepentingan

5. Penerapan Fungsi Kepatuhan Bank

6. Penerapan Fungsi Audit Intern

7. Penerapan Fungsi Audit Ekstern 
8. Penerapan Fungsi Manajemen Risiko dan Pengendalian Intern

9. Penyediaan Dana Kepada Pihak terkait dengan Debitur Besar

10. Transparansi Kondisi Keuangan dan Non Keuangan Bank, Laporan Pelaksanaan

Principles of good corporate governance

Good corporate governance dapat dikatakan selaras jika memiliki tiga aspek governance system yang mencakup governance structure, governance process dan governance outcome. Keselarasan yang dibentuk dari tiga aspek Governance system menghasilkan efektifitas corporate governance, hal itu terkait dengan kecukupan struktur yang pertama, yaitu governance structure dan infrastruktur tata kelola agar proses penerapan prinsip tata kelola yang baik menghasilkan outcome yang sesuai dengan harapan pemangku kepentingan (stakeholders). Struktur tata kelola terdiri dari unsur direksi, dewan komisaris, komite, dan satuan kerja Perseroan sedangkan Infrastruktur tata kelola meliputi kebijakan dan prosedur, sistem informasi manajemen serta tugas pokok dan fungsi masing-masing struktur organisasi. Kedua, Governance process dengan proses penerapan prinsip tata kelola yang baik yang didukung oleh kecukupan struktur dan infrastruktur tata kelola sehingga menghasilkan outcome yang sesuai dengan harapan pemangku kepentingan. Ketiga, governance outcome mencerminkan sejauh mana penerapan governance process dan dukungan yang memadai dari governance structure. Sebaliknya, permasalahan pada governance structure mengakibatkan timbulnya kelemahan pada governance process. Selanjutnya, adanya kelemahan pada governance process berdampak pada governance outcome.

Tujuan utama dari tata kelola perusahaan adalah untuk mencapai transparansi manajemen perusahaan bagi para pengguna laporan keuangan. Jika perusahaan bisa menerapkan konsep GCG ini maka transparansi kinerja manajemen akan berjalan dengan baik serta profitabilitas perusahaan diharapkan bisa terus meningkat. Manfaat perusahaan menerapkan GCG adalah sumberdaya (resources) yang dimiliki pemegang saham perusahaan dapat dikelola dengan baik, efisien dan dapat digunakan semata-mata untuk kepentingan pertumbuhan (nilai) perusahaan. Hal ini berarti bahwa Good Corporate Governance tidak hanya berakibat positif bagi pemegang saham namun juga bagi masyarakat luas berupa pertumbuhan 
Principles of good corporate governance

perekonomian nasional. Bank Mandiri merupakan salah satu Bank BUMN yang didirikan pada 2 Oktober 1998, merupakan bagian dari restrukturisasi perbankan yang dilaksanakan oleh pemerintah Indonesia dari empat bank pemerintah yaitu Bank Bumi Daya, Bank Dagang Negara, Bank Ekspor Impor Indonesia dan Bank Pembangunan. Beberapa penghargaan bergengsi diraih oleh Bank Mandiri diantaranya oleh Corporate Governance Perception Index (CGPI) yaitu program riset dan pemeringkatan penerapan GCG yang dilakukan oleh lembaga independen yaitu The Indonesian Institute for Corporate Governance (IICG). Bank Mandiri telah mengikuti penilaian CGPI selama 14 (empat belas) tahun berturut-turut sejak tahun 2003. Di tahun 2017 Bank Mandiri kembali meraih predikat "Sangat Terpercaya" sebanyak 11 kali berturut-turut. Selanjutnya penghargaan dengan kategori"The Best Overall" oleh The Indonesian Institute for Corporate Directorship (IICD) dalam ajang ASEAN CG Scorecard 2016.

Adapun yang menjadi rumusan masalah adalah bagaimanakah penerapan self assessment pada PT Bank Mandiri (Persero), Tbk. Tujuan penelitian ini untuk mengetahui hasil self assessment yang dilakukan berdasarkan -3 (tiga) aspek governance, yaitu governance structure, governance process, governance outcome.

\section{TINJAUAN TEORITIS}

1. Good Corporate Governance (GCG)

Tata Kelola Perusahaan dikenal dengan Corporate Governance adalah hubungan antara dewan direksi (board of directors), manajemen puncak (top management), dan para pemilik saham (shareholders) dalam menentukan arah dan performa perusahaan. GCG didefinisikan sebagai suatu pola hubungan, sistem, dan proses yang digunakan oleh organ perusahaan (Direksi, Dewan Komisaris, Rapat Umum Pemegang Saham (RUPS)) guna memberikan nilai tambah kepada pemegang saham secara berkesinambungan dalam jangka panjang, dengan tetap memperhatikan kepentingan stakeholders lainnya, berlandaskan peraturan GCG dapat disimpulkan sebagai: 
a. Suatu struktur yang mengatur pola hubungan tentang peran dewan komisaris, direksi, Rapat Umum Pemegang Saham (RUPS) dan para komisaris, direksi, Rapat Umum Pemegang Saham (RUPS) dan para sttaakeholder lainnya.

Principles of good corporate governance

b. Suatu sistem check and balance mencakup perimbangan kewwenaangnganan atas pengendalian perusahaan yang dapat membatasi munculnya dua peluang pengelolaan yang salah dan penyalahgunaan aset perusahaan.

c. Suatu prprooses yyang g trtrana sparan aatas pep nentuauann tujuan perusahaaaan pencapaian, dan pengukuran kinerjanya. pencapaian, dan pengukuran kinerjanya.

Menurut Sukamulja (2003), lingkungan yang dibutuhkan agar GCG dapat secara nyata diterapkan (King Commitee in West African Bankers Association Conference in South Africa, 2002) adalah:

a. Corporate discipline yaitu komitmen manajemen suatu perusahaan untuk bertindak benar dan pantas serta sadar untuk mendasarkan diri pada pada tata kelola good governance;

b. Transparency merupakan kemudahan atau akses pihak luar untuk menganalisis tindakan perusahaan dalam aspek fundamental ekonomi maupun pada aspek non keuangan;

c. Indepedence, kondisi ini diperlukan untuk menghindari potensi konflik yang mungkin disebabkan oleh CEO maupun para pemegang saham mayoritas;

d. Accountability, dalam suatu perusahaan, keputusan yang dibuat maupun diambil harus bersikap akuntabilitas, baik untuk keputusan maupun tindakannya;

e. Responsibility, manajemen bertanggungjawab terhadap para pemangku kepentingan (stakeholders) perusahaan agar perusahaan berada pada arah yang benar;

f. Fairness, sistem yang dibangun harus seimbang dan adil bagi semua pihak dalam perusahaan;

g. Social reponsibility, perusahaan yang peduli dengan tanggung jawab sosial akan memperoleh keuntungan ekonomi secara tidak langsung seperti meningkatnya produktivitas dan reputasi perusahaan. 
Principles of good corporate governance

\section{9}

\section{Prinsip-prinsip Good Corporate Governance (GCG)}

Dalam penerapannya untuk melaksanakan GCG dalam suatu perusahaan dibutuhkan prinsip-prinsip sehingga GCG bisa terlaksanakan dengan baik. Menurut (Komite Nasional Kebijakan Governance) KNKG (Zarkasyi, 2008), prinsipprinsip GCG yaitu:

a. Transparansi (Transparancy)

Untuk menjaga objektivitas dalam menjalankan bisnis, perusahaan harus menyediakan informasi yang material dan relevan dengan cara yang mudah diakses dan dipahami oleh pemangku kepentingan. Perusahaan harus mengambil inisiatif untuk mengungkapkan tidak hanya masalah yang diisyaratkan oleh peraturan perundang-undangan, tetapi jugahal yang penting untuk pengambilan keputusan olehpemegang saham, kreditur dan pemangku kepentingan lainnya. Disini ada 2 indikator yang dipakai dalam menilai transparansi perusahaan yaitu informasi dan kebijakan dalam perusahaan.

b. Akuntabilitas (Accountability)

Perusahaan harus dapat mempertanggung jawabkan kinerjanya secara transparan dan wajar. Untuk itu perusahaan harus dikelola secara benar, terukur dan sesuai dengan kepentingan perusahaan dengan tetap memperhitungkan kepentingan pemegang saham dan pemangku kepentingan lainnya. Akuntabilitas merupakan persyaratan yang diperlukan untuk mencapai kinerja yang berkesinambungan. Dalam menilai akuntabilitas sebuah perusahaan bisa dilihat dari 2 indikator yaitu basis kerja dan audit.

c. Responsibilitas (Responsibility)

Perusahaan harus mematuhi peraturan perundang-undangan serta melaksanakan tanggung jawab terhadap masyarakat dan lingkungan sehingga dapat terpelihara kesinambungan usaha dalam jangka panjang dan mendapat pengakuan Good Corporate Citizen CSR (Corporate Social Responsibility) dan kepatuhan (compliance) terhadap peraturan perundangundangan.

d. Independensi (Independency)

Untuk melancarkan pelaksanaan prinsip GCG, perusahaan harus dikelola secara independen sehingga masing-masing organ perusahaan tidak saling mendominasi dan tidak dapat diintervensi oleh pihak lain. Ada 2 indikator untuk 
menilai independensi perusahaan yaitu pengaruh internal dan pengaruh eksternal.

Principles of good corporate governance

e. Kesetaraan dan Kewajaran (Fairness)

Dalam melaksanaakan kegiatannya, perusahaan harus senantiasa memperhatikan kepentingan pemegang saham, pemangku kepentingan lainnya dan semua orang yang terlibat didalamnya berdasarkan prinsip kesetaraan dan kewajaran. Untuk menilai kesetaraan dan kewajaran yang terjadi dalam perusahaan ada 2 indikator yang bisa dilihat yaitu shareholder dan stakeholder. Dengan menerapkan prinsip-prinsip GCG yang ada diharapkan perusahaan bisa berjalan secar efektif dan efisien, sehingga kinerjanya menjadi optimal.

\section{METODE PENELITIAN}

Dalam penelitian ini menggunakan pendekatan kualitatif yang dikumpulkan dari berbagai sumber yang dapat menghasilkan data deskriptif yang bermaksud untuk memahami fenomena tentang apa yang dialami oleh subjek penelitian misalnya perilaku, persepsi, motivasi, tindakan, dan lain-lain; secara holistik, dan dengan cara deskripsi dalam bentuk kata - kata dan bahasa, pada suatu konteks khusus yang alamiah dan dengan memanfaatkan berbagai metode alamiah" (Moleong, 2012). Pengumpulan data menggunakan library research dengan data sekunder yang diperoleh dari Laporan GCG Bank Mandiri untuk tahun 2013 - 2017.

Adapun Teknik analisis data yang dilakukan sebagai berikut:

1. Mengumpulkan laporan GCG Bank Mandiri

2. Meninjau penerapan GCG

3. Membuat Rekapitulasi penilaian peringkat dan nilai komposit

4. Membandingkan dengan aspek pelaksanaan GCG

\section{HASIL PENELITIAN DAN PEMBAHASAN}

Good Corporate Governance (GCG) adalah suatu tata kelola Bank yang menerapkan prinsip-prinsip keterbukaan (transparency), akuntabilitaas (accountability), pertangunggjawaban (responsibility), independensi (independency), dan kewajaran (fairness) dalam melaksanakan aktivitas bisnis. GCG menunjukkan pola hubungan antara Manajemen dengan stakeholders, 
Principles of good corporate governance

Manajemen dengan Dewan Komisaris dan antar Manajemen yang didasarkan pada etika dan Corporate Culture Values yang ditunjang oleh suatu sistem, proses, pedoman kerja dan organisasi untuk mencapai kinerja yang maksimal. Berikut merupakan maksud dan tujuan Good Corporate Governance yang tertuang di dalam tata tertib GCG Bank Mandiri adalah:

a. Meningkatkan kesungguhan Manajemen dalam menerapkan prinsip-prinsip keterbukaan, akuntabilitas, tanggung jawab, independensi, kewajaran dan kehati-hatian dalam pengelolaan Bank

b. Meningkatkan kinerja Bank, efisiensi dan pelayanan kepada stakeholders

c. Menarik minat dan kepercayaan investor

d. Memenuhi kepentingan shareholders atas peningkatan shareholder values

e. Melindungi Bank dari intervensi politik dan tuntutan hukum

Pada tahun 2013 - 2014 penilaian self assessment telah dilakukan menunjukkan bahwa Bank Mandiri memperoleh nilai komposit 2 dengan predikat "Baik", hasil self assessment dimaksud telah memperoleh feedback dari Bank Indonesia dengan hasil penilaian peringkat 2 atau Baik yang mencerminkan Bank telah melakukan penerapan Good Corporate Governance yang secara umum baik. Hal ini tercermin dari pemenuhan yang memadai atas prinsip-prinsip GCG. Hal ini tercermin dari pemenuhan yang memadai atas prinsip-prinsip GCG. Apabila terdapat kelemahan dalam penerapan pronsip GCG, maka secara umum kelemahan tersebut kurang signifikan dan dapat diselesaikan dengan tindakan normal oleh manajemen bank. Untuk tahun 2015 - 2017 diperoleh hasil peringkat 1 atau sangat baik. Apabila terdapat kelemahan dalam penerapan prinsip Good Corporate Governance, maka secara umum kelemahan tersebut kurang signifikan dan dapat diselesaikan dengan tindakan normal oleh manajemen Bank.

Tabel 1. Nilai dan Kriteria GCG Bank Mandiri

\begin{tabular}{|c|c|c|}
\multicolumn{3}{c}{ Tahun $2013-2017$} \\
\hline TAHUN & GCG & KRITERIA \\
\hline $\mathbf{2 0 1 3}$ & 2,00 & Baik \\
\hline $\mathbf{2 0 1 4}$ & 2,00 & Baik \\
\hline $\mathbf{2 0 1 5}$ & 1,00 & Sangat Baik \\
\hline $\mathbf{2 0 1 6}$ & 1,00 & Sangat Baik \\
\hline $\mathbf{2 0 1 7}$ & 1,00 & Sangat Baik \\
\hline
\end{tabular}




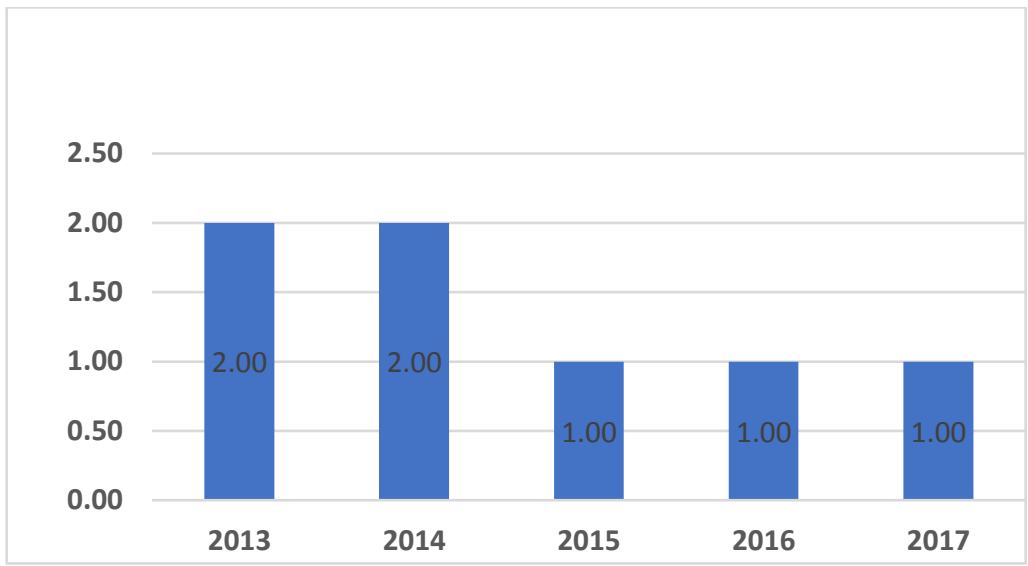

Principles of good corporate governance

Gambar 1. Nilai dan Kriteria GCG Bank Mandiri

Tahun 2013 - 2017

Mekanisme GCG merupakan proses penerapan prinsip yang didukung oleh kecukupan struktur dan infrastruktur tata kelola bank sehingga sesuai dengan harapan pemangku kepentingan Perseroan. Organ Perseroan Terbatas yang tertinggi adalah Rapat Umum Pemegang Saham (RUPS) mempunyai hak dan kewenangan yang tidak dimiliki oleh Direksi dan Komisaris. Dilihat dari sudut peranannya dalam Perseroan RUPS mempunyai peranan yang sangat penting. RUPS berwenang untuk mengangkat dan memberhentikan anggota Dewan Komisaris dan Direksi, melakukan evaluasi kinerja Dewan Komisaris dan Direksi, menyetujui perubahan dan pengesahan Anggaran Dasar, menyetujui, laporan tahunan dan menetapkan bentuk dan jumlah remunerasi anggota Dewan Komisaris dan Direksi serta mengambil keputusan terkait tindakan korporasi atau keputusan strategis lainnya yang diajukan Direksi, alokasi penggunaan laba dan pembagian dividen.

Keputusan dalam RUPS didasarkan pada kepentingan Perseroan. RUPS tidak dapat melakukan intervensi terhadap tugas, fungsi, serta wewenang Dewan Komisaris dan Direksi dengan tidak mengurangi wewenang RUPS untuk menjalankan haknya sesuai dengan Anggaran Dasar dan peraturan. Bank Mandiri menjamin untuk memberikan segala keterangan yang berkaitan dengan Perseroan kepada pemegang saham, sepanjang tidak bertentangan dengan kepentingan perusahaan dan peraturan perundang-undangan, dengan demikian proses tata kelola dapat berjalan dengan baik. Bentuk kepatuhan Bank Mandiri terhadap peraturan dan perudangan-undangan yang berlaku adalah dipenuhinya self assessment tata kelola sesuai Surat Edaran Bank Indonesia. 
Principles of good corporate governance

Penilaian sendiri dilakukan secara komperehensif dan terstruktur dengan mengintegrasikan faktor-faktor penilaian ke dalam 3 (tiga) aspek governance, yaitu governance structure, governance process, governance outcome. Berikut ini Corporate Governance Framework Bank Mandiri:

\section{3}

Governance Structure

Organ Utama

- Organ Pendukung

- Infrastruktur

Corporate

Governance

\section{Governance Process}

Alokasi wewenang, tugas dan tanggung jawab yang efektif:

- Penetapan Strategi dan Sasaran

- Pemilihan dan pengawasan human capital yang efektif

Pengolahan Bank yang professional

- Melindungi kepentingan nasabah, memenuhi kepentingan pemegang saham, dan pemangku kepentingan lainnya

- Memadukan budaya, kegiatan usaha dan perilaku dengan tujuan menjalankan kegiatan usaha yang aman dan sehat dengan integritas dan patuh terhadap peraturan perundang-undangan

- Menetapkan fungsi pengendalian yang efektif

\section{Governance Process}

\section{Pemenuhan} harapan para pemangku kepentingan

Sumber: Laporan GCG Bank Mandiri tahun 2017

Gambar 2. Governance Framework

\section{Governance Structure}

Berdasarkan Undang-Undang Republik Indonesia Nomor 40 tahun 2007 tentang Perseroan Terbatas (UU PT), Organ Perseroan terdiri dari RUPS, Dewan Komisaris dan Direksi. Sistem kepengurusan menganut sistem dua badan (two tier system) yaitu Dewan Komisaris dan Direksi, yang memiliki wewenang dan tanggung jawab yang jelas sesuai fungsinya masing-masing sebagaimana diamanahkan dalam anggaran dasar dan peraturan perundang-undangan.

Undang-undang No. 40 tahun 2007 tentang Perseroan Terbatas dan Peraturan Otoritas Jasa Keuangan No. 33/POJK.04/2014 tentang Direksi dan Dewan Komisaris Emiten atau Perusahaan Publik, mengharuskan seluruh perusahaan yang bernaung di 
bawah hokum Indonesia untuk memiliki Dewan Komisaris yang bertugas mengawasi kebijakan manajemen, proses manajemen di dalam perusahaan, sekaligus mengawasi dan memberikan saran/nasihat kepada Direksi. Governance Structure mencakup

Principles of good corporate governance pelaksanaan tugas dan tanggungjawab Komisaris dan Direksi serta kelengkapan dan pelaksanaan tugas komite. Berikut governance structure tahun 2017 untuk Dewan Komisaris dan Dewan Direksi:

a. Pelaksanaan tugas dan tanggung jawab Dewan Komisaris

- Komisaris Utama

Berdasarkan Tata Tertib Dewan Komisaris Bank Mandiri, tugas dan tanggung jawab Komisaris Utama Bank Mandiri, antara lain sebagai berikut:

a) Melakukan pemanggilan Rapat Dewan Komisaris secara tertulis yang disampaikan kepada seluruh anggota Dewan Komisaris dengan mencantumkan acara, tanggal, waktu dan tempat rapat.

b) Bertindak sebagai Ketua Rapat dalam Rapat Dewan Komisaris.

c) Memastikan pelaksanaan Rapat Dewan Komisaris dan Rapat KomiteKomite Dewan Komisaris terlaksana termasuk ketertiban Risalah Rapat.

d) Menerima laporan-laporan dari Komite-Komite di bawah Dewan Komisaris.

e) Mengkoordinasikan semua tugas Dewan Komisaris yang sedapat mungkin telah dibagi rata secara merata.

- Dewan Komisaris

Dewan Komisaris berkewajiban untuk:

a) Mengesahkan dan mengawasi pelaksanaan RKAP.

b) Melakukan pengawasan atas tindak lanjut dari temuan terhadap penyimpangan berdasarkan peraturan perundangan, anggaran dasar dan prudential banking practices.

c) Mengikuti perkembangan kegiatan Perseroan, dan dalam hal Perseroan menunjukkan gejala kemunduran, apabila diperlukan Dewan Komisaris dapat menyelenggarakan RUPS untuk melaporkan kepada pemegang saham dengan disertai saran mengenai langkah-Iangkah perbaikan yang harus ditempuh. 
Principles of good corporate governance

d) Memberikan pendapat dan saran kepada RUPS mengenai setiap persoalan yang dianggap penting bagi kepengurusan Perseroan.

Penilaian kerja dewan komisaris dilakukan oleh pemegang saham dalam RUPS tahunan yang disampaikan dalam laporan tugas pengawasan dewan komisaris. Adapun yang menjadi kriteria evaluasi kinerja dewan komisaris meliputi:

a) pelaksanaan tugas dan fungsi pengawasan,

b) kepatuhan terhadap peraturan yang berlaku,

c) tingkat kesehatan bank,

d) tingkat kehadiran anggota dewan komisaris dalam rapat maupun komite dibawah pengawan dewan komisaris, dan keterlibatan dalam penugasanpenugsan tertentu.

Hasil self assessment GCG pada tahun semester I dan semester II tahun 2017 memperoleh komposit 1 ("sangat baik)

b. Pelaksanaan tugas dan tanggung jawab Direksi

Direksi adalah Organ Perseroan yang berwenang dan bertanggung jawab penuh atas pengurusan Perseroan untuk kepentingan Perseroan, sesuai dengan maksud dan tujuan Perseroan serta mewakili Perseroan, baik di dalam maupun di luar pengadilan sesuai dengan ketentuan Anggaran Dasar. Dalam melaksanakan tugasnya, Direksi wajib mencurahkan tenaga, pikiran, perhatian dan pengabdiannya secara penuh pada tugas, kewajiban dan pencapaian tujuan Perseroan.

- Tugas dan Tanggung Jawab Direksi

Tugas pokok Direksi Perseroan sesuai dengan Anggaran Dasar adalah sebagai berikut:

a) Menjalankan dan bertanggung jawab atas pengurusan Perseroan untuk kepentingan serta sesuai dengan maksud dan tujuan Perseroan yang ditetapkan dalam Anggaran Dasar dan bertindak selaku pimpinan dalam pengurusan tersebut.

b) Memelihara dan mengurus kekayaan Perseroan. Direksi bertanggung jawab penuh dalam melaksanakan tugasnya untuk kepentingan Perseroan dalam mencapai maksud dan tujuan Perseroan.

- Hak dan Wewenang Direksi 
Direksi mempunyai hak dan wewenang antara lain:

a) Menetapkan kebijakan yang dipandang tepat dalam kepengurusan Perseroan.

Principles of good corporate governance

b) Mengatur penyerahan kekuasaan Direksi untuk mewakili atau beberapa orang yang khusus ditunjuk untuk itu termasuk pegawai Perseroan baik sendiri maupun bersama-sama dan/atau kepada badan lain.

c) Mengatur ketentuan tentang pegawai Perseroan termasuk penetapan upah, pensiun, atau jaminan hari tua dan penghasilan lain bagi pegawai Perseroan berdasarkan peraturan perundangundangan.

d) Mengangkat dan memberhentikan pegawai Perseroan berdasarkan peraturan ketanagakerjaan dan peraturan perundang-undangan lainnya.

e) Mengangkat dan memberhentikan Sekretaris Perusahaan dan/ atau Kepala Satuan Pengawas Intern dengan persetujuan Dewan Komisaris.

f) Menghapusbukukan piutang macet dengan ketentuan sebagaimana diatur dalam Anggaran Dasar dan yang selanjutnya dilaporkan kepada Dewan Komisaris selanjutya dilaporkan dan dipertanggungjawabkan dalam Laporan Tahunan.

g) Tidak menagih lagi piutang bunga, denda, ongkos, dan piutang lainnya dalam rangka restrukturisasi dan/atau penyelesaian piutang serta melakukan perbuatan lain dalam rangka penyelesaian piutang Perseroan dengan kewajiban melaporkan kepada Dewan Komisaris yang ketentuan dan tata cara pelaporannya ditetapkan oleh Dewan Komisaris.

h) Melakukan segala tindakan dan perbuatan lainnya mengenai pengurusan maupun pemilikan kekayaan Perseroan, mengikat Perseroan dengan pihak lain dan/atau pihak lain dengan Perseroan, serta mewakili Perseroan di dalam dan di luar Pengadilan tentang segala hal dan segala kejadian, dengan pembatasan sebagaimana diatur dalam peraturan perundangundangan, Anggaran Dasar dan/atau keputusan RUPS., untuk membangun sinergi dan aliansi bisnis yang kuat antara Bank Mandiri dan Perusahaan Anak. 
Principles of good corporate governance

\section{7}

Penilaian kerja dewan direksi dilakukan oleh pemegang saham dalam RUPS tahunan mengacu pada key performance indicators (KPI) yang telah disepakati oleh pemegang saham, dewan komisaris, dan direksi, yaitu:

a) Perspektif keuangan dan pasar

b) Fokus pelanggan

c) Efektivitas produk dan proses

d) Fokus tenaga kerja

e) Kepemimpinan, tata kelola dan CSR

Pihak yang melakukan assessment kinerja direksi adalah dewan komisaris dan RUPS. Adapun hasil self assessment GCG Bank Mandiri pada tahun 2017 adalah komposit 1 ("Sangat Baik"). Apabila terdapat kelemahan dalam penerapan prinsip Good Corporate Governance, maka secara umum kelemahan tersebut kurang signifikan dan dapat diselesaikan dengan tindakan normal oleh manajemen Bank.

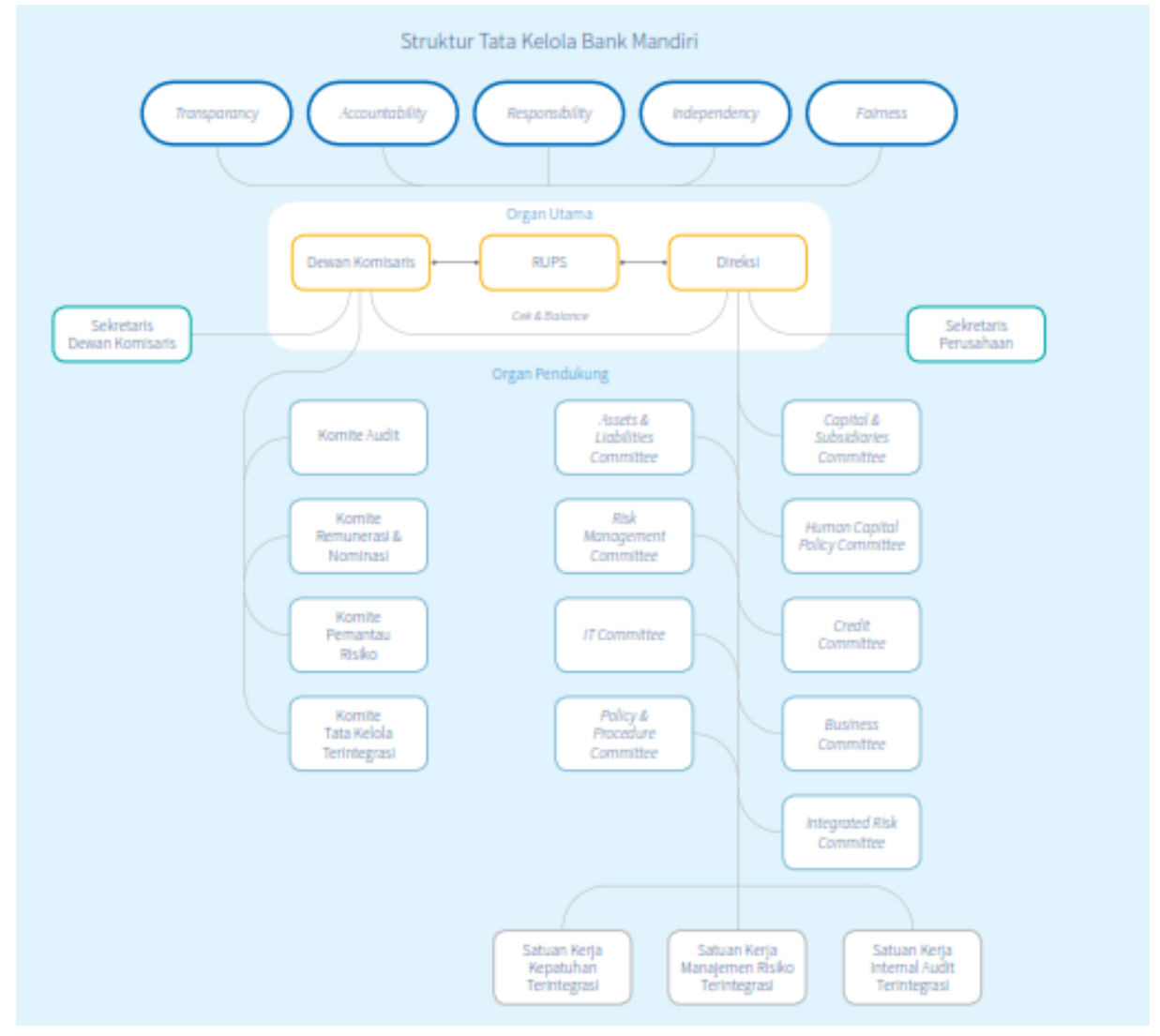

Sumber: Laporan GCG Bank Mandiri tahun 2017

Gambar 3. Struktur Tata Kelola Bank Mandiri 
Sejalan dengan ketentuan Undang-undang Perseroan Terbatas Nomor 40 Tahun 2007, maka struktur GCG Bank Mandiri terdiri dari RUPS, Dewan Komisaris dan Direksi. Pelaksanaan tata kelola perusahaan dilakukan secara sistematis dan berkesinambungan sehingga prinsip-prinsip GCG menjadi acuan dalam kegiatan seharihari Bank Mandiri. Untuk memaksimalkan fungsi pengawasannya, Dewan

Principles of good corporate governance Komisaris membentuk komite-komite antara lain Komite Audit, Komite Remunerasi dan Nominasi, Komite Pemantau Risiko dan Komite Tata Kelola Terintegrasi. Dalam menjalankan tugas dan kewajibannya, masing-masing komite Dewan Komisaris bekerja sesuai dengan ruang lingkup tugas komite yang bersangkutan yang ditetapkan dengan Surat Keputusan Dewan Komisaris. Selain itu, Dewan Komisaris dibantu oleh Sekretaris Dewan Komisaris yang membantu kelancaran administrasi pelaksanaan tugas dan tanggung jawab Dewan Komisaris. Dalam mengelola, mengendalikan, mengawal dan bertanggung jawab atas kegiatan operasional dan implementasi tata kelola perusahaan, Direksi dibantu oleh komite di bawah Direksi dan Sekretaris Perusahaan. Selain itu, sejalan dengan POJK 18/ POJK.03/2014 tentang Tata Kelola Terintegrasi, Bank Mandiri membentuk Satuan Kerja Kepatuhan Terintegrasi, Satuan Kerja Manajemen Risiko Terintegrasi dan Satuan Kerja Audit Intern Terintegrasi

\section{Governance Process}

Governance Process mencakup penerapan fungsi kepatuhan bank, penanganan benturan kepentingan, penerapan fungsi audit intern dan ekstern, penerapan manajemen risiko termasuk sistem pengendalian intern, penyediaan dana kepada pihak terkait dan dana besar, serta sistem rencana strategis bank.

a. Fungsi kepatuhan

Dewan Komisaris memastikan terselenggaranya good corporate governance dalam setiap kegiatan usaha serta kebijakan tata kelola perusahaan, termasuk didalamnya pelaksanaan kepatuhan. Penilaian risiko kepatuhan dalam RBBR dilaporkan kepada Dewan Komisaris setiap 6 (enam) bulan sekali untuk mendapatkan feedback.

b. Fungsi Audit Internal

Melakukan pengujian secara objektif atas suatu bukti dalam rangka memberikan penilaian yang independen atas kecukupan internal control, risk management 
Principles of good corporate governance dan governance process dalam organisasi. Internal Audit bertanggung jawab secara langsung kepada Direktur Utama dan berkomunikasi dengan Dewan Komisaris melalui Komite Audit.

c. Manajemen Resiko dan Pengendalian Internal

Bank Mandiri menjalankan praktik pengelolaan risiko yang efektif di seluruh Unit Kerja dengan menerapkan kebijakan Three line of defense models dengan ketentuan sebagai berikut:

a) Unit Kerja sebagai risk owner merupakan first line of defense yang bertanggungjawab terhadap pengelolaan risiko unit kerjanya.

b) Unit Risk Management berperan sebagai second line of defense yang menjalankan fungsi oversight.

c) Unit Internal Audit sebagai third line of defense yang menjalankan fungsi independent assurance.

Pelaksanaan Sistem Pengendalian Internal atas fungsi Manajemen Risiko merupakan tanggung jawab bersama baik first, second maupun third line of defense. Bank Mandiri menjalankan Proses Identifikasi, Pengukuran, Pemantauan, Pengendalian Risiko, dan Sistem Informasi Manajemen Risiko melalui kerangka kerja Enterprise Risk Management (ERM). Bank Mandiri senantiasa meningkatkan kapabilitas dan pengetahuan seluruh pegawai terutama dalam hal pengelolaan risiko, dengan menyelenggarakan pelatihan internal secara rutin melalui Risk Management Academy. Selain itu, Bank Mandiri juga secara rutin minimal sekali dalam setahun mengadakan sosialisasi, forum diskusi, magang, maupun program mengenai manajemen risiko yang sejalan dengan internalisasi budaya perusahaan. Bank Mandiri mengkomunikasikan manajemen risiko kepada Dewan Komisaris melalui Komite Pemantau Risiko dan Komite Tata Kelola Terintegrasi.

\section{Governance Outcomes}

Penilaian governance outcome bertujuan untuk menilai kualitas outcome yang memenuhi harapan stakeholders yang merupakan hasil proses pelaksanaan prinsip GCG yang didukung oleh kecukupan struktur dan infrastruktur tata kelola Perseroan. 
Yang termasuk dalam governance outcome mencakup aspek kualitatif dan aspek kuantitatif, antara lain yaitu:

a. Kecukupan transparansi laporan

b. Kepatuhan terhadap peraturan perundang-undangan.

c. Perlindungan konsumen.

d. Obyektivitas dalam melakukan assessment/audit.

e. Kinerja bank seperti rentabilitas, efisiensi, dan permodalan.

f. Peningkatan/penurunan kepatuhan terhadap ketentuan yang berlaku dan penyelesaian permasalahan yang dihadapi bank

Bank Mandiri menyampaikan melalui publikasi informasi baik melalui media cetak maupun situs web Perseroan. Dalam situs website Bank Mandiri, terdapat segala informasi yang terkait dengan Keterbukaan Informasi. Selain website, memanfaatkan teknologi dan aplikasi media sosial lainnya seperti SMS Banking, Phone Banking, Mobile Banking, Instagram, Facebook dan Twitter. Publikasi informasi yang dapat di akases oleh publik, antara lain:

a. Laporan Keuangan Bulanan melalui situs web BI dan Bank Mandiri.

b. Laporan Keuangan Triwulan melalui media cetak dan situs web Perseroan.

c. Laporan Tahunan Bank Mandiri yang disusun dan disajikan sesuai ketentuan dan disampaikan kepada regulator, rating agency,lembaga pengembangan perbankan, lembaga/institusi riset dan majalah keuangan dan dipublikasikan melalui situs web Perseroan.

d. Laporan Tahunan Tata Kelola Perusahaan, Visi, Misi, Nilai Perusahaan Komposisi dan Profil Dewan Komisaris dan Direksi, serta ketentuan internal terkait tata kelola mulai dari Anggaran Dasar hingga Piagam Komite-komite yang juga dipublikasikan melalui situs web Perseroan.

e. Informasi Produk dan Layanan Perusahaan termasuk jaringan kantornya dipublikasikan melalui Laporan Tahunan dan situs webPerseroan, agar nasabah, investor dan masyarakat luas dapat dengan mudah mengakses informasi atas produk dan layanan Perseroan.

f. Informasi Prosedur Penyampaian Pengaduan, Kebijakan Keamanan Informasi dan Tips bagi Nasabah dalam menggunaklayanan perbankan yang 
Principles of good corporate governance dipublikasikan melalui situs web Perseroan untuk pelaksanaan ketentuan perlindungan konsumen.

g. Informasi lainnya yang bertujuan untuk mendukung keterbukaan informasi, edukasi keuangan dan layanan kepada masyarakat.

Efektivitas penerapan GCG tercermin dari governance outcome yang telah diperoleh. Perseroan dan para pemangku kepentingan telah mendapatkan manfaat dari penerapan GCG dengan dicapainya kinerja keuangan maupun operasional yang baik di tahun 2017 sebagai berikut.

a. Pertumbuhan Kredit sebesar 9,99\%

b. Pertumbuhan Dana Pihak Ketiga sebesar 6,77\%

c. Pertumbuhan Aset $8,28 \%$

d. Pertumbuhan Ekuitas 10,85\%

e. Pertumbuhan Laba Tahun Berjalan 46,37\%

f. Penurunan NPL turun $0,54 \%$ menjadi $3,45 \%$

Di samping itu, efektivitas penerapan GCG juga bisa dilihat dari kepatuhan terhadap peraturan perundang undangan dan tidak dikenakannya sanksi dalam perkara hukum yang dihadapi oleh Perseroan. Perseroan juga mendapatkan manfaat dari penerapan GCG dengan menurunnya temuan audit, dari 689 temuan di tahun 2016 menjadi 349 di tahun 2017.

\section{SIMPULAN DAN SARAN}

Berdasarkan hasil self assessment yang telah dilakukan oleh bank mandiri pada tahun 2013 - 2017 bahwa GCG tahun 2013 - 2014 predikat baik sedangkan tahun 2015 - 2017 manajemen Bank telah melakukan penerapan Good Corporate Governance yang secara umum sangat baik. Adapun penilaian sendiri yang telah dilakukan secara komperehensif dan terstruktur dengan mengintegrasikan faktorfaktor penilaian governance structure, governance process, governance outcome sudah baik. Hal ini tercermin dari pemenuhan yang memadai atas prinsip-prinsip Good Corporate Governance. Apabila terdapat kelemahan dalam penerapan prinsip Good Corporate Governance, maka secara umum kelemahan tersebut kurang signifikan dan dapat diselesaikan dengan tindakan normal oleh manajemen Bank. Bank Mandiri perlu mengembangkan dan memutakhirkan kebijakan dan pedoman 
pelaksanaan RUPS dan pengambilan keputusan dalam RUPS yang memberikan nilai tambah pada Pemegang Saham perusahaan, selai itu untuk meningkatkan GCG yang semakin baik perlunya mengembangkan kebijakan dan pedoman secara

Principles of good corporate governance berkelanjutan.

\section{DAFTAR PUSTAKA}

Adrian Sutedi. 2012. Good Corporate Governance. Jakarta: Sinar Grafika

Bursa Efek Indonesia. https://www.idx.co.id/perusahaan-tercatat/laporan-keuangan-dantahunan/

Desti Maharani. 2012. Analisis Mekanisme Corporate Governance Perusahaan Terhadap Pemilihan Auditor Eksternal. 1-34

FCGI. 2008. Peranan dewan komisaris dan komite audit dalam pelaksanaan corporate governance (Tata Kelola Perusahaan) Jilid II. Jakarta: Citragraha.

Hak-Hak Istimewa demi Kelangsungan Usaha. Jakarta: Prenada Media Grou

Jasa Keuangan Lainnya. Bandung: Alfabeta

Komite Nasional Kebijakan Governance (KNKG). 2006. Pedoman Umum Good Corporate Governance Indonesia. Jakarta

Mochammad Ridwan dan Ardi Gunardi. 2013. Peran Mekanisme Corporate Governance sebagai Pemoderasi Praktik Earning Management terhadap Nilai Perusahaan. Trikonomika. Vol 12. No 1. 49-60

Moleong, J. L. (2012). Metodologi penelitian kwalitatif. Bandung: Remaja Rosda karya.

Muh. Arief Effendi. 2016. The Power of Good Corporate Governance Teori dan Implementasi. Edisi 2. Jakarta: Salemba Empat

Muhammad Khafid. 2012. Pengaruh Tata Kelola Perusahaan (Corporate Governance) dan StrukturKepemilikan Terhadap Persistensi Laba. Jurnal Dinamika Akuntansi. Vol 4. No 2. 139-148 


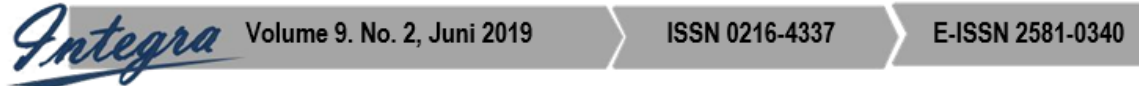

Principles of good corporate governance
Peraturan Menteri Negara BUMN Nomor: Per-01/MBU/2011 tanggal 1 Agustus 2011 tentang Penerapan Tata Kelola Perusahaan yang Baik (Good Corporate Governance) pada Badan Usaha Milik Negara

Peraturan Menteri Negara BUMN Nomor: Per-09/MBU/2012 tanggal 6 Juli 2012 Tentang Perubahan Atas

Peraturan Otoritas Jasa Keuangan Nomor 4/POJK.03/2016 tentang Penilaian Tingkat Kesehatan Bank Umum,

Peraturan Otoritas Jasa Nomor 55/POJK.03/2016 tentang Penerapan Tata Kelola Bagi Bank Umum

PT Bank Mandiri (Persero) Tbk.

https://www.bankmandiri.co.id/web/gcg/implementation-of-corporate-governance

Sugiyono. 2015. Metode Penelitian Kuantitatif Kualitatif dan R\&D. Bandung: Alfabeta

Surya, Indra \& Ivan Yustiavandana. (2006). Penerapan Good Corporate Governance Mengesampingkan Hak-hak Istimewa demi Kelangsungan Usaha. Jakarta: Prenada Media Group

Zarkasyi, Wahyudin. (2008). Good Corporate Governance Pada Badan Usaha Manufaktur, Perbankan, dan Jasa Keuangan Lainnya. Bandung: Alfabeta 